\title{
MAKNA UNGKAPAN TRADISIONAL DALAM MASYARAKAT BIMA
}

\author{
1Nurmiwati 2Fahidah \\ ${ }^{1}$ Dosen Program Studi Pendidikan Bahasa dan Sastra Indonesia \\ ${ }^{2}$ Mahasiswa Program Studi Pendidikan Bahasa dan Sastra Indonesia \\ FKIP Universitas Muhammadiyh Mataram \\ Nurmiwati1986@gmail.com
}

\begin{abstract}
ABSTRAK
Makna penggunaan ungkapan bergantung pada pilihan kata atau kalimat yang digunakan oleh masyarakat dalam melakukan interaksi dalam kehidupan sosial masyarakat. Penggunaan ungkapan dalam kehidupan sehari-hari hanya digunakan jika penutur ingin menyampaikan tujuan dan maksud dalam hal yang positif maupun yang negatif. Penyampain sindiran dapat disampaikan dengan ungkapan yang halus maupun ungkapan yang tidak halus seperti ungkapan yang digunakan dalam masyarakat Bima. Penelitian ini bertujuan untuk mengetahui tentang makna ungkapan yang disampaikan oleh masyarakat Bima. Penelitian ini menggunakan metode deskripsi kualitatif dalam melakukan analisis data. Sedangkan untuk penggumpulan data peneliti menggunakan teknik observasi, wawancara, catat, rekam, dokumentasi dan teknik terjemahan. Langkah-langkah penganalisisan data dengan menggunakan yakni reduksi, penyederhanaan, penyajian, deskripsi dan penarikan simpulan. Hasil penelitian ini ditemukan adanya penggunaan makna ungkapan diantaranya; 1) menasehati, 2) memotifasi, 3) memberikan dukungan, 4) mengingatkan, 5) menyadarkan,dan 6) melengkapi, dan 7) menyemangati
\end{abstract}

Kata kunci: makna ungkapan, tradisional, masyarakat Bima

\section{PENDAHULUAN}

Bahasa adalah media yang diwariskan secara turun temurun oleh masyarakat pengguna bahasa itu sendiri. Sistem pewarisan bahasa cenderung kita jumpai dalam dua cara yaitu diwariskan secara lisan dan tertulis. Penggunaan bahasa secara lisan merupakan hal yang paling banyak kita jumpai dalam kehidupan sehari-hari, hal itu dikarenakan dalam melakukan interaksi dalam kehidupan sehari-hari bahasa lisan menjadi media utama yang menghubungkan antara satu dengan yang lainnya karena bahasa lisan merupakan cara yang paling cepat untuk menyampaikan maksud dan tujuan kita kepada orang lain. Cara penyampaian maksud dan tujuan kepada orang lain tidak hanya disampaikan lewat komunikasi biasa tetapi juga dapat disampaikan dengan menggunakan ungkapan.

Penggunaan ungkapan dalam menyampaikan pesan kepada orang lain dapat menimbulkan hal yang positif ataupun negatif tergantung dari si penerima pesan dalam mengartikan pesan yang disampaikan dalam ungkapan. Penggunaan ungkapan dalam menyampaikan pesan kepada orang laun tidak hanya hidup dan berkembang dalam bahasa Indonesia saja tetapi dalam bahasa daerahpun masi bertahan digunakan dalam kehidupan masyarakat tiap daerah. Di Indonesia terdapat 
beraneka ragam bahasa, bahkan jumlahnya sangat banyak. Hal ini disebabkan oleh banyaknya suku dengan adatnya masing-masing dinegara.Setiap suku memiliki bahasa tersendiri dan tentu saja dipelihara oleh penuturnya.Namun demikian bangsa Indonesia dikenal oleh dunia justru karena kekayaannya yang berupa keragaman suku, adat, bahasa dan budaya.

Penggunaan ungkapan memiliki tujuan dan maksud tertentu dalam penggunaannya sehingga perlu kita kaji lebih dalam makna yang dimaksudkan dalam ungkapan yang digunakan oleh penutur kepada lawan tuturnya. Pbegitu juga dalam penggunaan ungkapan yang disampaikan oleh masyarakat di kabupaten Bima. Ungkapan tradisional dalam masyarakat Bima merupakan salah satu jenis folklor yang mengandung nilai estetik. Unsur estetik tersebut dapat dilihat dari bentuk yang membangunnya. Unsur unsur bentuk meliputi, diksi, tema, dan amanat. Di samping bentuk estetik (tersebut ungkapan tradisional) dalam masyarakat Bima tidak terlepas dari fungsinya dalam masyarakat pendukungnya. Oleh karena itu bentuk dan fungsi ungkapan tradisional dalam masyarakat Bima ini menjadi fokus penelitian. Seperti yang di kemukakan di atas bahwa bentuk dan fungsi ungkapan yang hidup dan yang di anut oleh masyarakat berabad abad lamanya itu terus bergeser dan bukan mustahil pada akhirnya hilang. Hal ini di sebabkan oleh 1) kehadiran normal-normal dan nilainilai baru sebagai akibat dari kemajuan teknologi komonikasi canggih, 2) pewarisan ungkapan dari generasi lama ke generasi baru dilakukan secara lisan yang pada umumnya mudah di lupakan dan hilang. Seandainya dilakukan secara tertulis mungkin akan mudah disimpan, dirawat, dan tahan lama.

Untuk dapat mengetahui tentang ungkapan yang digunakan dalam bahasa Bima maka perlu dilakukan penelitian tentang sejauh mana bertahannya penggunaan ungkapan dalam masyarakat Bima. Untuk bisa mengetahui beratahan atau tidaknya tentang penggunaan ungkapan dalam masyarakat Bima maka perlu dilakukan penelitian terlebih dahulu yang berkaitan dengan makna penggunaan ungkapan dalam masyarakat Bima.

\section{LANDASAN TEORI}

Penggunaan referensi dalam tulisan ini menjadi syarat dan menjadi pegangan bagi para penulis dalam menentukan arah tulisan dan kualitas yang dihasilkan oleh penulis. Tulisan ini bersumber dari hasil penelitian yang dilakukan dengan menggunakan beberapan landasan teori yang berkaitan dengan hal-hal sebagai berikut.

\subsection{Pengertian ungkapan tradisional}

Bahasa Indonesia/Ungkapan. Ungkapan merupakan gabungan kata yang maknanya sudah menyatu dan tidak ditafsirkan dengan makna unsur yang membentuknya. Idiom atau disebut juga dengan ungkapan adalah gabungan kata yang membentuk arti baru dimana tidak berhubungan dengan kata pembentuk dasarnya.

Ungkapan tradisional merupakan gabungan dua kata yaitu "ungkapan" dan "tradisional". Ungkapan adalah segala sesuatu yang diungkapkan yang berwujud gabungan kata yang maknanya 
tidak sama dengan pengaduan makna setiap kata yang membentuk ungkapan itu (dalam T. Fatimah, 1997: 14). Ungkapan adalah susunan beberapa kata yang mempunyai arti tunggal. Ungkapan tidak dapat diartikan secar aksara (literally). Ia mempunyai arti khusus dalam bahasa inggris dapat disamakan dengan idiom (dalam M. Ali K, 1996 : 5). Idiom berarti kebiasaan khusus dalam bahasa, bentuk bahasa berupa gabungan kata yang makna katanya tidak dijabarkan dari makna unsur gabungan. Sedangkan tradisional merupakan sikap dan cara berpikir serta bertindak yang selalu berpegang tegu pada norma dan adat kebiasaan yang ada secara turuntemurun (dalam Ananda Santoso,1995: 367).

Menurut Alan Dundes, peribahasa atau ungkapan tradisional sukar sekali didefinisikan, bahkan, menurut Archer Taylor peribahasa tidak mungkin diberi definisi. Pendapat Archer Taylor ini kurang disetujui oleh Alan Dundes. Menurut Alan Dundes, biarpun sukar, kita dapat mencari jalan lain untuk melakukannya. Misalnya, dengan mempergunakan ungkapan tradisional untuk menerangkan pribahasa. Cervantes mendevinisikan "ungkapan tradisional sebagai kalimat pendek yang disarikan dari pengalaman yang panjang". Sedangkan Bertrand Russel menganggapnya sebagai "kebijaksanaan" orang banyak yang merupakan kecerdasan seseorang (the wisdom of many, the with of one)" (dalam Dananjaja, 1984: 28).

Dari beberapa pengertian ungkapan tradisional tersebut dapat disimpulkan bahwa ungkapan tradisonal adalah foklor lisan yang sudah lazim digunakan oleh masyarakat secara turuntemurun, hidup dan berkembang dalam masyarakat dalam bentuk kalimat pendek dan sederhana.

\subsection{Fungsi Ungkapan}

Fungsi-fungsi itu menurut William R. Bascom (dalam Danandjaja, 1984: 19) ada empat yaitu:

1. Sebagai sistem proyeksi (projective device). yakni sebagai alat pencermin angan-angan suatu kolektif.

2. Sebagai alat pengesahan pranatapranata dan lembaga-lembaga kebudayaan.

3. Sebagai alat pendidikan anak (pendagogical device).

4. Sebagai alat pemaksa dan pengawas agar normal-normal masyarakat akan slalu dipatuhi anggota kolektifnya.

Fungsi dari pada idiom atau ungkapan adalah untuk memberi makna terhadap suatu kondisi tertentu, menghaluskan informasi dalam komunikasi. Sedangka menurut Kridalaksana (1983: 131) "fungsi ungkapan peribahasa adalah dipergunakan untuk menghias karangan, pangajaran atau pedoman hidup" (dalam Sudiartha, 1993 : 10). Selanjutnya seperti bahasa lisan pada umumnya, peribahasa atau ungkapan juga sebagai alat komunikasi, terutama dalam hal-hal penyendalian masyarakat (social control), yang secara konkret untuk mengkritik seorang yang telah melanggar norma masyarakat. Mencela seseorang dengan mempergunakan peribahasa lebih muda diterima dan lebih mengenai sasarannya dari pada celaan langsung. Hal ini disebabkan peribahasa atau 
ungkapan adalah tidak bersifat perseorangan (impersonal), sehingga walaupun diucapkan orang tertentu, namun tidak dapat di identifikasikan dengan orang itu. Jadi, fungsi peribahasa atau ungkapan yang cukup penting, yakni untuk memamerkan kepandaian seseorang, karena dengan mampu mengucapkan kebanyakan peribahasa atau ungkapan oleh sekelompok orang yang memiliki ciri-ciri, pengenal fisik maupun kebudayaannya. Ia akan disegani sebagai orang yang bijak. jadi dapat juga dikatakan peribahasa atau ungkapan berfungsi sebagai alat untuk memperoleh gengsi dalam masyarakat (Danandjaja, 1984 : 33).

\subsection{Makna Ungkapan}

Penggunaan ungkapan dala kehidupan sehari-hari memiliki tujuan dan maksud dalam penyampainnya, tergantung dari ungkapan atau idiom yang digunakan oleh si penuturkepada lawan tuturnya. Ungkapan di gunakan dalam berkomunikasi hanya digunakan oleh masyarakat penutur apabila ingin menyampaikan hal tertentu, tergantung dari ungkapan yang digunakan oleh si penutur. Adapun makna yang biasanya digunakan oleh masyarakat pengguna ungkapn pada umumnya adalah sebagai berikut : 1) menasehati, 2) memotifasi, 3) memberikan dukungan, 4) mengingatkan, 5) menyadarkan,dan 6) melengkapi, dan 7) menyemangati.

\subsection{Contoh Ungkapan}

"Membanting tulang" Dalam makna sebenarnya, Membating tulang bisa diartikan tulang yang dibanting. Namun dalam arti ungkapan membanting tulang artinya adalah bekerja keras.

\section{METODE PENELITIAN}

Penggunaan metode yang tepat dalam sebuah penelitian dapat memberikan hasil yang maksimal dalam penelitian yang kita lakukan begitu pula peneltian ini. Metode yang digunakan peneliti adalah penelitian kualitatif dengan tujuan untuk memaparkan data sebagaimana adanya. Data yang dikumpulkan diperoleh dengan menggunakan teknik observasi, teknik rekam, teknik catat dan teknik dokumentasi dan teknik terjemahan. Data yang terkumpul dianalisis dengan menggunakan metode identifikasi, melakukan klasifikasi dan dilengkapi dengan interpretasi data.

\section{HASIL DAN PEMBAHASAN}

1. Data Ungkapan Tradisional Masyarakat Bima

\begin{tabular}{|l|l|l|l|}
\hline No & \multicolumn{1}{|c|}{ Ungkapan } & \multicolumn{1}{|c|}{ Artinya } & \multicolumn{1}{|c|}{ Maknanya } \\
\hline 1 & Aina ca "u ntanda ese & $\begin{array}{l}\text { Jangan suka lihat ke } \\
\text { atas }\end{array}$ & $\begin{array}{l}\text { Jangan iri dan } \\
\text { sombong }\end{array}$ \\
\hline 2 & $\begin{array}{l}\text { Aina kamaru madara } \\
\text { kamidi ade, linggapu } \\
\text { sadumpu nepipu rui } \\
\text { Bada }\end{array}$ & $\begin{array}{l}\text { Jangan menidurkan } \\
\text { mata dan mendiamkan } \\
\text { hati berbantallah kayu } \\
\text { berkasurlah duri } \\
\text { kaktus }\end{array}$ & $\begin{array}{l}\text { Jangan bermalas- } \\
\text { malas, berusaha } \\
\text { dan bekerja } \\
\text { keraslah }\end{array}$ \\
\hline
\end{tabular}




\begin{tabular}{|c|c|c|c|}
\hline 3 & $\begin{array}{l}\text { Dodopu tando } \\
\text { tambari kontu }\end{array}$ & $\begin{array}{l}\text { Pandanglah ke depan } \\
\text { dan tengoklah ke } \\
\text { belakang }\end{array}$ & $\begin{array}{l}\text { Introspeksi diri } \\
\text { baik dalam bertutur } \\
\text { kata,bertingkahlaku } \\
\text { maupun dalam hal- } \\
\text { hal lain. }\end{array}$ \\
\hline 4 & Maja labo dahu & Malu dan takut & Malu dan takut \\
\hline 5 & $\begin{array}{l}\text { Likipu loko ndaimu } \\
\text { ampo muliki loko } \\
\text { dou }\end{array}$ & $\begin{array}{l}\text { Cubit dahulu perutmu } \\
\text { sendiri baru mencubit } \\
\text { perut orang lain }\end{array}$ & $\begin{array}{l}\text { Jangan berbuat } \\
\text { semena-mena atau } \\
\text { menyakiti orang } \\
\text { lain }\end{array}$ \\
\hline 6 & $\begin{array}{l}\text { Mbolo radampapu, } \\
\text { makatantu dirawi }\end{array}$ & $\begin{array}{l}\text { Rapat dan } \\
\text { musyawarahlah apa } \\
\text { yang harus dilakukan }\end{array}$ & $\begin{array}{l}\text { Suatu pekerjaan, } \\
\text { tindakan, dalan } \\
\text { keputusan } \\
\text { diputuskan melalui } \\
\text { keputusan bersama. }\end{array}$ \\
\hline 7 & $\begin{array}{l}\text { Aina kani ilmu bi"a } \\
\text { o"o ese dihanta ma } \\
\text { awa ditonda }\end{array}$ & $\begin{array}{l}\text { Jangan pake ilmu } \\
\text { belah bambu, yang } \\
\text { atas diangkat yang } \\
\text { bawah diinjak }\end{array}$ & $\begin{array}{l}\text { Jangan terlalu } \\
\text { menyanjung- } \\
\text { nyanjung orang } \\
\text { sudah tinggi } \\
\text { kedudukannya } \\
\text { (kaya) sebaliknya } \\
\text { jangan } \\
\text { meremehkan orang } \\
\text { yang rendah posisinya }\end{array}$ \\
\hline 8 & $\begin{array}{l}\text { Ruku ampo wara } \\
\text { diraka (kaya) ampo } \\
\text { wara dimalempi }\end{array}$ & $\begin{array}{l}\text { Gerak baru ada yang } \\
\text { didapat, jalan baru ada } \\
\text { yang menopang }\end{array}$ & $\begin{array}{l}\text { Berusaha dan } \\
\text { bekerja dahulu } \\
\text { baru mendapatkan } \\
\text { hasil }\end{array}$ \\
\hline 9 & $\begin{array}{l}\text { Edera nahu sura dou } \\
\text { labo dana }\end{array}$ & $\begin{array}{l}\text { Tidak usah aku asal } \\
\text { orang dan tanah }\end{array}$ & $\begin{array}{l}\text { Jangan mementingkan } \\
\text { diri sendiri } \\
\text { yang penting } \\
\text { rakyat dan bangsa }\end{array}$ \\
\hline 10 & $\begin{array}{l}\text { Karoci mataho } \\
\text { kangeri maiha }\end{array}$ & $\begin{array}{l}\text { Mempercepat yang } \\
\text { baik, memperlambat } \\
\text { yang tidak baik }\end{array}$ & $\begin{array}{l}\text { Berlomba-lomba } \\
\text { melakukan yang } \\
\text { baik dan } \\
\text { menghindari hal- } \\
\text { hal yang tidak baik. }\end{array}$ \\
\hline 11 & $\begin{array}{l}\text { Oi moti cou ma } \\
\text { kandangana }\end{array}$ & $\begin{array}{l}\text { Air laut siapa yang } \\
\text { asinkan }\end{array}$ & $\begin{array}{l}\text { Berlomba-lomba } \\
\text { melakukan yang } \\
\text { baik dan }\end{array}$ \\
\hline
\end{tabular}




\begin{tabular}{|c|c|c|c|}
\hline & & & $\begin{array}{l}\text { menghindari hal- } \\
\text { hal yang tidak baik. }\end{array}$ \\
\hline 12 & $\begin{array}{l}\text { Lembo ade paja } \\
\text { saramu }\end{array}$ & Lebar hati luas pikiran & $\begin{array}{l}\text { Lapang dada dan } \\
\text { sabar }\end{array}$ \\
\hline 13 & $\begin{array}{l}\text { Kese tahopu dua, } \\
\text { dua tahopu tolu }\end{array}$ & $\begin{array}{l}\text { Satu lebih baik dua, } \\
\text { dua lebih baik tiga } \\
\text { (orang) }\end{array}$ & $\begin{array}{l}\text { Satu lebih baik } \\
\text { berdua, dua lebih baik } \\
\text { bertiga (orang) }\end{array}$ \\
\hline 14 & Nggahi rawi pahu & $\begin{array}{l}\text { Berkata dan rupa } \\
\text { (hasil) }\end{array}$ & $\begin{array}{l}\text { Satunya ucapan } \\
\text { dengan perbuatan }\end{array}$ \\
\hline 15 & $\begin{array}{l}\text { Ma nduku si sawa } \\
\text { aina dimpoka kaina } \\
\text { wobo, dimbala kaina } \\
\text { dana }\end{array}$ & $\begin{array}{l}\text { Jika kamu memukul } \\
\text { ular jangan sampai } \\
\text { cambuknya patah, } \\
\text { tanahnya berbekas }\end{array}$ & $\begin{array}{l}\text { Bersikap bertindak } \\
\text { hati-hati dan } \\
\text { bijaksana supaya } \\
\text { tidak merugikan } \\
\text { orang lain. }\end{array}$ \\
\hline 16 & Teka doro londo sori & $\begin{array}{l}\text { Mendaki gunung dan } \\
\text { menurungi sungai }\end{array}$ & $\begin{array}{l}\text { Untuk } \\
\text { mendapatkan } \\
\text { rejeki kita harus } \\
\text { berusaha dan } \\
\text { bekerja keras. }\end{array}$ \\
\hline 17 & Weli kalinci dei karu & $\begin{array}{l}\text { Membeli kelinci dalam } \\
\text { karung }\end{array}$ & $\begin{array}{l}\text { Laki-laki } \\
\text { hendaklah berhati- } \\
\text { hati dalam memilih } \\
\text { calon istri. }\end{array}$ \\
\hline 18 & $\begin{array}{l}\text { Satoi-toi pea ndadi } \\
\text { ore }\end{array}$ & $\begin{array}{l}\text { Sedikit-sedikit nanti } \\
\text { menjadi banyak }\end{array}$ & $\begin{array}{l}\text { Setiap usaha itu } \\
\text { dilakukan sedikit } \\
\text { demi sedikit, tetapi } \\
\text { akhirnya akan } \\
\text { berhasil dengan } \\
\text { baik. }\end{array}$ \\
\hline 19 & $\begin{array}{l}\text { Hi"i sanggi"i peke } \\
\text { saatako }\end{array}$ & $\begin{array}{l}\text { Daging sekarat tulang } \\
\text { sebatang }\end{array}$ & Kita adalah satu. \\
\hline 20 & $\begin{array}{l}\text { Ma lanta laba mpa } \\
\underline{\text { dicua dula labo }}\end{array}$ & $\begin{array}{l}\text { Hanya kain putih (kain } \\
\text { kasar) yang menemani } \\
\text { (bila kita meninggal) }\end{array}$ & $\begin{array}{l}\text { Tidak ada yang } \\
\text { bisa membantu } \\
\text { kita di alam akhirat } \\
\text { kecuali perbuatan }\end{array}$ \\
\hline & & & baik kita sendiri. \\
\hline 21 & $\begin{array}{l}\text { Na to"i si angi } \\
\text { hintipu aina, na na"e } \\
\text { c angi co"opu aina }\end{array}$ & $\begin{array}{l}\text { Kalau angin kecil } \\
\text { tariklah talinya, kalau } \\
\text { angin besar lepas } \\
\text { talinya }\end{array}$ & $\begin{array}{l}\text { Hendaklah } \\
\text { bijaksana dan adil } \\
\text { dalam mengambil } \\
\text { keputusan. }\end{array}$ \\
\hline
\end{tabular}




\begin{tabular}{|c|c|c|c|}
\hline 22 & $\begin{array}{l}\text { Paki ponggo sarinci } \\
\text { tobe pingga }\end{array}$ & $\begin{array}{l}\text { Membuat kapak } \\
\text { memungut pecahan } \\
\text { piring }\end{array}$ & $\begin{array}{l}\text { Membuat sesuatu } \\
\text { yang sudah pasti } \\
\text { (tapi kecil) demi } \\
\text { mengejar sesuatu } \\
\text { yang besar (tapi } \\
\text { pasti) }\end{array}$ \\
\hline 23 & $\begin{array}{l}\text { Edera ngghi di lenga } \\
\text { ponda ndai ma lengi }\end{array}$ & $\begin{array}{l}\text { Jangan bilang pada } \\
\text { kawan labu sendri } \\
\text { yang bocor }\end{array}$ & $\begin{array}{l}\text { Jangan } \\
\text { membicarakan } \\
\text { kejelekan orang } \\
\text { lain,kita sendiri } \\
\text { mempunyai } \\
\text { kejelekan } \\
\text { kekurangan }\end{array}$ \\
\hline 24 & $\begin{array}{l}\text { Ndaina bou wira loja } \\
\text { nahu waura wara di } \\
\text { sabae. }\end{array}$ & $\begin{array}{l}\text { Anda baru } \\
\text { mengembangkan layar } \\
\text { saya telah sampai di } \\
\text { seberang }\end{array}$ & $\begin{array}{l}\text { Melakukan } \\
\text { pekerjaan jangan } \\
\text { sampe lengah atau } \\
\text { lambat. }\end{array}$ \\
\hline 25 & $\begin{array}{l}\text { Aina weli sahe ade } \\
\text { diwu }\end{array}$ & $\begin{array}{l}\text { Jangan membeli } \\
\text { kerbau dalam lubuk }\end{array}$ & $\begin{array}{l}\text { Bila membeli barang } \\
\text { harus melihat rupanya } \\
\text { terlebih dahulu }\end{array}$ \\
\hline
\end{tabular}


2. Makna dan Penggunaan Ungkapan Tradisional Masyarakat Bima

\section{1) Aina ca"u ntanda ca ese}

Maknanya Jangan iri dan sombong

Ungkapan ini mengandung pengertian bahwa sikap iri terhadap orang lain, sikap membanding-bandingkan diri sendiri denagn orang lain adalah tidak baik. Misalnya tetangga punya rumah mewah, dia juga ingin memiliki rumah mewah meski tidak berkemampuan untuk itu. Demikian juga orang kaya, perhatikan keadaan nasib orang miskin disekitarnya, janganlah terlalu mengejar kepentingan pribadi tampa memperhatikan orang disekitarnya. Hal ini kemungkinan seseorang berbuat hal-hal tercela untuk memperoleh sesuatu yang diinginkannya, dengan cara apapun demi memenuhi keinginannya.

Penggunaan

Pada umumnya ungkapan ini biasa digunakan untuk memberi nasihat atau peringatan kepada orang lebih muda usianya atau masing kurang pengetahuannya agar ia selalu waspada dan tidak iri terhadap kekayaan atau kelebihan orang lain.

2) Aina kamaru mada ro kamidi ade, linggapu sadumpu nepipu rui bada

maknanya jangan bermalas-malas, berusaha dan bekerja keras.

Ungkapan ini bermakna bermalas-malasan; menganjurkan untuk selalu bekerja keras. Ungkapan bagian pertama "aina kamaru mada ro kamidi ade" mengandung pengertian bahwa tidur dan bermalasmalasan itu tidak baik dan tidak menguntungkan. Sedangkan bagian keduanya "linggapu sadumpu nepipu rui bada" bermakna bahwa meskipun banyak kesulitan atau hambatan kita harus tetap berusaha dan bekerja keras. Jadi penekanan ini adalah adalah larangan bermalasmalasan dan anjuran berusaha atau bekerja keras.
Biasanya ungkapan ini digunakan untuk memberi nasihat kepada orang yang suka bermalas-malsan atau bagi anak yang hendak merantau ke negeri orang. Hal ini dianggap sebagai bekal dalam mengarungi kehidupan yang penuh tantangan.

\section{3) Dodopu tando ro tambari kontu}

Maknanya Introspeksi diri baik dalam bertutur kata, tingakahlaku, maupun dalam hal-hal lain.

Ungkapan ini mengandung ajaran agar setiap orang senantiasa mengenal diri sendiri dan tidak berlebihan pada orang lain. Artinya kita sendirilah yang harus lebih mengenali diri dan perbuatan yang kita lakukan. Baik dan buruknya perbuatan yang kita lakukan harus kita sadari sendiri terlebih dahulu sebelum orang lain mengingatkan kita akan perbuatan kita.

Ungkapan yang terdapat pada data 3 di atas biasanya digunakan untuk menasehati orang lain agar mengenali diri dan perbuatan yang dilakukannya sendiri sebelum orang lain menilai yang dilakukannya.

4)

\section{Maja labo dahu}

maknanya Malu dan takut

Anjuran kepada manusia agar takut kepada Allah dan malu kepada manusia lainya. Malulah seandainya tidak melakukan perbuatan yang baik dsan benar seperti melakukan perintah Allah. Takutlah kepada Allah akan perbuatan yang merugikan diri sendiri dan orang lain. Takut dan malu itu sangat penting dalam kehidupan karna kalau kedua hal ini dipegang teguh niscaya akan terhindar dari perbuatan yang tidak baik, hina dan dosa.Dengan demikian kita akan selamat baik dunia maupun akhirat.

Digunakan oleh orang tua kepada anaknya yang akan menuntut ilmu di perantauan orang. Orang tua sering mengungkapkan ini di saat anak-anak ynag meninggalkan kampung halamannya. Petuah dan nasehat tersebut disampaikan kepada seorang anak dengan penuh harapan mereka terhindar dari perbuatan yang dilarang oleh agaman 
dan memperoleh keselamatan dalam meniti perjuangan dirantauan.

5) Likipu loko ndaimu ampo muliki loko dou

Maknanya Jangan berbuat semena-mena atau menyakiti orang lain

Ungkapan ini mengingatkan kita agar selal mempertimbangkan segala sesuatu sebelum bertindak terutama kepada sesama lakukan introspeksi diri baik dalam bertutur kata,bertingkah laku tidak baik, sombong, menganggap dirinya seolah-olah dia yang paling pintar, benar, sehingga selalu meremehkan orang lain dengan demikian seyogyanya, kita saling mencintai sesama, tenggangrasa dan menjunjung tinggi nilai kemanusian.

Ungkapan ini biasa diungkapkan mengingat agar orang tidak sombong dan meremehkan orang lain, agar orang mengerjakan sesuatu sesuai dengan kemampuannya. manusia. Kita hendaknya tidak berbuat semena-mena atau menyakiti orang lain. Kita pada umumnya merasa tidak tenang disakiti, demikian juga orang lain. Kaena itu janganlah menyakiti orang lain.

Ungkapan ini biasa diucapkan untuk mengingatkan orang agar tidak menyakiti orang lain, sebelum bertindak ia hendaknya mempertimbangkan segala sesuatunya. Ungkapan ini ditujukan kepada orang yang biasa menyakiti orang lain, orang yang kurang memperhatikan perasaan orang lain dan orang yang tidak mencintai sesama.

6) Mbolo radamapu, makatantu dirawi

Maknanya Suatu pekerjaan, tindakan dan keputusan dapat diputuskan melalui kesepakatan bersama dalam rapat Suatu pekerjaan, tindakan, keputusan, dan sebagainya dapat diputuskan melalui kesepakatan dalam rapat. Hal ini hasil rembukan dan bahasan bersama lebih utama, daripada hasil pemikiran sendiri. Karena melalui rapat, banyak hal dan persoalan dapat dibahas serta dipertimbangkan sebelum menghasilkan sesuatu keputusan.

Digunakan oleh anggota keluarga, kelompok organisasi anggota masyarakat, pemuka agama dan sebagainya, untuk bermusyawarah dalam mengambil keputusan karna keputusan bersama itu lebih bagus, daripada mengambil keputusan sendiri.

7) Aina kani ilmu bi "a o"o, ma ese dihanta ma awa ditonda

Maknanya Jangan terlalu menyanjung-nyanjung orang yang sudah tinggi kedudukannya (kaya) sebaliknya jangan meremekan orang yang rendah posisinya (miskin).

Ungkapan ini bermakna larangan untuk berbuat adil dan sewenang-wenang terhadap orang lain, orang sudah tinggi kedudukanya justru diangkat dan disanjung-sanjung sebaliknya yang rendah kedudukanya justru ditekan dan diinjakinjak.

Ungkapan ini biasa digunakan kepada pemimpin, pemegang kekuasaan, orang kaya dan semacamnya agar berlaku adil terhadap siapa saja, tidak membedakan ras, keturunan, dan status melainkan berdasarkan sikap dan tingkah lakunya. Ungkapan biasanya digunakan oleh para sesepu kepada pemimpin, orang tua kepada anaknya, atau orang lain yang lebih muda umurnya dan sering berbuat sewenangwenang.

8) Ruku ampo wara diraka, lampa ampo wara dimalempi

Maknanya Berusaha dan bekerja dahulu baru mendapat hasil.

Ungkapan ini berisi anjuran agar kita berusaha dan bekerja untuk memperoleh sesuatu. Dengan kata lain segala sesuatu tidak akan datang sendiri tampa kita usaha. Oleh karena itu berusaha dan bekerjalah agar sesuatu dapat diperleh.

Ungkapan ini untuk mengingatkan orang yang malas, tidak berusaha untuk memperoleh sesuatu. Dia hanya menunggu 
uluran tangan orang lain atau turunya rejeki itu dari langit.

9) Edera nahu sura dou la bo dana

Maknanya Tidak usah aku yang penting rakyat dan bangsa

Ungkapan ini menggambarkan kepentingan orang banyak di atas kepentingan pribadi, golongan, keturunan. Kata dou dan dana mengacu kepada orang banyak dan negara. Jadi umum atau orang banyak selalu didahulukan, daripada kepentingan diri sendiri, golongan tertentu, ketururunan dan keluarga tertentu seyokyanya dinomor duakan.

Dalam penggunaan sehari-hari, ungkapan ini selalu diungkapkan oleh orang yang mengutamakan kepentingan dan kemaslahatan orang banyak serta ditujukan kepada orang yang senantiasa mementingkan diri sendiri, golongan, dan keturuanan sendiri.

10) Karoci mataho kangeri maiha

Maknanya Berlomba-lomba melakukan yang baik dan menghindari halhal yang tidak baik.

Berisi anjuran agar kita selalu mempercepat dan berlomba- lomba melakukan yang baik. Selalu menghindari dan mempertimbangkna dengan cermat dalam mengerjakan hal-hal yang tidak baik. Mempercepat artinya hendaknya segera melakukan hal yang baik itu, karena dikhawatirkan apabila hal itu ditunda atau tidak berkesempatan lagi untuk mengerjakannya disebabkan pekerjaan yang kita hadapi, kondisi badan yang tidak memungkinkan, sakit atukah mati. Sebaliknya kita hendaknya menunda hal-hal yang tidak baik, karena dengan penundaan itu pikiran kita akan berubah atau kesempatan untuk itu semakin sempit atau tidak ada dan harus menghindari perbuatan yang hina dan dosa.

Sering digunakan pada majelis-majelis ta'lim, ceramah-ceramah agama, acara perkawinan, selamatan dan sebagainya.Tujuannya adalah untuk mengingatkan kita semua untuk mengerjakan hal yang baik untuk mendapat barokah dan pahala dari-NYA.

\section{1) Oi moti cou ma kandangana Maknanya jangan suka memuji diri} sendiri

Ungkapan ini bermakna larangan bagi orang yang suka memuji dirinya. Seseorang memuji diri atau membanggakan diri sendiri adalah orang sombong yang akan menjerumuskan kesifat takabur. Sebagai seorang manusia tentu ada kelemahannya. Di satu pihak seorang mungkin hebat, tetapi dalam hal lain ada kelemahannya. Jangan lantas memuji diri bila melakukan sesuatu. Seperti diketahui, yang mengasini air laut memang zat garam, bukan benda lain. Tetapi tidaklah berarti zat garam itu boleh menyombongkan diri karena telah mengasihi air laut yang luas.

Sering digunakan pada ceramah-ceramah agama.Tujuannya adalah untuk mengingatkan kita semua agar tidak memuji diri sendiri secara berlebihan

\section{2) Lembo ade paja sara mu}

Maknanya lapang dada dan sabar

Ungkapan ini menggambarkan seseorang berlapang dada dan sabar. Seseorang yang memiliki sifat seperti di atas biasanya banyak menyumbangkan pikiran dan tenaganya bagi kepentingan masyarakat. Orang yang berlapang dada tidak akan mengerjakan sesuatu yang bertentangan dengan hati nuraninya. Hidupnya dikendalikan oleh pendirian. Ia tidak termaksud orang kaya yang pelit atau orang pandai yang sombong. Ia adalah orang yang mulia selalu membantu orang lain. Semua itu patut dicontohi, diteladani, dan diamalkan.

Digunakan oleh anggota keluarga, organisasi. Ungkapan tersebut dicontoh, diteladani, dan diamalkan dalam kehidupan sehari-hari.

13) Kese tahopu dua,dua tahopu tolu Maknanya satu lebih baik, dua lebih baik tiga (orang) 
Ungkapan ini mengandung
pengertian bahwa hasil pemikiran, keputusan, pekerjaan kelompok/orang banyak lebih baik dari pada hasil pemikiran perorangan. Tingkat kecermatan dan kesempurnaan suatu hasil karya lebih bisa dipeoleh melalui kerjasama orang banyak daripada kerja sendiri.

Ungkapan ini digunakan dalam pertemuan, kegiatan ceramah, sarasehan dan sebagainya. Ungkapan ini biasa diucapkan para cerdik pandai kepada orang yang lebih muda dan masih kurang pengalaman.

\section{4) Nggahi rawi pahu}

dengan perbuatan

Maknanya satunya ucapan

Ungkapan ini mengandung pengertian satu kata dengan perbuatan. Suatu ungkapan harus direalisasikan dengan perbuatan sehingga mencapai suatu hasil. Seseoarng harus konsekuen terhadap ucapannya, tidak membual dan omong kosong.

Ungkapan ini sudah menjadi semboyan, suatu ucapan harus biasa direalisasikan dalam bentuk yang nyata. Ungkapan ini biasa juga dijadikan alat untuk mengeritik seseorang, kelompok, lembaga, atau pemimpin, dan lain sebagainya untuk mengingatka terhadap sesuatu yang telah diucapkannya.

15) Ma nduku si sawa aina dimpoka kaina wobo,dimbala kaina dana

Maknanya bersikap, bertindak hati-hati dan bijaksana supaya tidak merugikan orang lain.

Jika menghadapi persoalan, kita harus bersikap bijaksana dan hati-hati sehingga tujuan tercapai tampa ada pihak yang dirugikan. Ungkapan ini mengibaratkan kegiatan atau usaha mencapai tujuan dengan memukul ular, jangan sampai tongkat pemukulnya patah dan tanahnya berbekas. Hal ini mengandung pengertian bahwa dalam usaha mencapai apa yang diinginkan, kita harus hati-hati dan tidak perlu menyabit kiri kanan yang justru menyakiti dan berbekas dihati orang lain.

Ungkapan ini biasa digunakan untuk mengingatkan orang-orang yang suka menyabit kiri dan kanan dalam usaha mewujudkan cita-citanya. Mereka todak memperdulikan orang disekitarnya, yang penting tujuanya tercapai.

16) Teka doro londo sori

Maknanya untuk mendapatkan

rezeki kita harus berusaha dan berkerja keras

Pekerjaan mencari nafkah atau rejeki yang halal bukan persoalan yang mudah, melainkan perlu kerja keras, kemauan baja, berusahayang tekun dan penuh kesabaran. Tampa itu maka rejeki atau nafkah itu tidak akan datang dengan sendirinya. Oleh karena itru kita dianjurkan agar mau berkerja keras, agar kesejahteraan dapat tercapai.

Digunakan oleh para pemuka agama, anggotan masyarakat disaat memberikan ceramah, petuah atau nasehat perkawinan kepada anggota masyarakat, generasi muda yang merantau dan sebagainya. Ungkapn itu dapat dijadikan pedoman hidup mereka dalam menempuh hidup atau perantauan. Dalam mengarungi hidup ini perlu kerja keras dan kemauan yang membaja.

17) Weli kalinci dei karu

Maknanya laki-laki hendaklah berhati-hati dalam m,emili calon istri Ungkapan ini berisi anjuran agar laki-laki hendaklah kalau meminang perempuan terlebih dahulu mengenal atau melihat perempuan itu agar supaya tidak menyesal dikedian hari. Banyak para remaja terutama jaman dahulu yang dalam menempuh hidup barunya tidak mengetahui atau mengenal perempuan calon istrinya. Kelinci dalam karung itu dapat dikenali bentuknya, apakah kelinci itu baik atau buruk. Demikian pula bila meminang perempuan yang belum dilihat dan dikenalnya, Kalau tiba-tiba perempuan itu cacat mental atau fisik akibatnya agar terjadi ketimpangan 
kehidupan yang sukar dihapus dan diingatnya. Oleh karena itu dalam memilih seorang perempuan, kenali dan lihatlah sepaham mungkin perempuan idamannya itu, baik kelakuan, wajahnya, dan lain-lain.

Ungkapan ini digunakan untuk mengingatkan laki-laki agar dalam memilih calon istri hendaklah terlebih dahulu mengenal dan melihat perempuan idamannya itu, baik kelakuannya, wajahnya, agamanya, pendidikanya, baru orang tua dan keturunannya. Semua itu menjaga agar supaya tidak terjadi penyesalan yang terusmenerus.

18)

Satoi-satoi pea ndadi ore

Maknanya setiap usaha itu diklakukan sedikit demi sedikit, tetapi akhirnya akan berhasil dengan baik.

Ungkapan ini bahwa setiap usha yang dilakukan sedikit demi sedikit, tetapi akhirnya akan berhasil dengan baik. Orang yang sunggu-sunggu, tentu akan mendapat jalan bagi usahanya untuk mencapai tujuannya yaitu usaha yang maju. Orang yang berusaha maju itu tidak muda seperti teori yang didiskusikan. Akan tetapi harus dengan tekun, ketelitian, kesabaran, penuh tanggung jawab, serta dijalankan tidak dengan setengah-setengah.

19)

$$
\begin{aligned}
& \text { Hi"i sanggi"i peke satako } \\
& \text { Maknanya Kita adalah satu } \\
& \text { Ungkapan ini diibaratkan dengan }
\end{aligned}
$$

daging dan tulang masih bersatu, saling melekat dan sulit dipisahkan. Ungkapan ini adanya hubungan erat antar sesama, hubungan yang harus dipelihara dan dibina seutuhnya.

Ungkapan ini untuk mengingat orang lain bahwa kita ini sesama, dan berasal dari sumber yang sama. Untuk itu kita seyogyanya meperhatikan keutuhan hubungan kekeluargaan dan persahabatan demi terwujudnya persatuan bangsa.

20) Ma landa laba mpa dicua dula
la $\underline{b}$ o menjadi bekal kita menuju akhirat
Jika meninggal dunia hanya kain kafan yang akan menemani kita keliang lahat. Sedangkan keluarga, kerabat,dan harta benda tidak dapat menemani kita. Ungkapan ini agar kita selalu ingat bahwa kematian akan datang kepada kita sebagai mahluk hidup, juga mengingatkan kepada kita agar senantiasa pebuat baik sebagai bekal dikemudian hari nanti ( akhirat).

Ungkapan ini sering didengar pada acaraacaara ceramah keagamaan, upacara kematian, dan sebagainya. Ungkapan ini biasa diajukan kepada umum atau orang banyak agar selalu sadar dan mempersiapkan diri dengan perbuatan yang baik sebagai bekal di alam baka.

21) Nato"i sic angi hintipu aina, na na"e si angi co"opu aina

Maknanya hendaklah bijaksana dan adil dalam mengambil keputusan.

Ungkapan ini mengandung ajaran agar berhati-hati, biksana dalm mengambil keputusan. Kata tali (ai) di sini yaitu tali digunakan untuk bermain layang-layang. Apabila anginnya kencang sehingga tali layang-layang tegang hendaaknya diulur dan diatur supaya tidak putus. Sebaliknya jika angin lemah, hendaklah talinya ditarik dan dikencangkan supaya layang-layng itu tidak turun. Oleh karena itu dalam menghadapi masalah hendaklah mempertimbangkan segala sesuatunya, disesuaikan dengan situasi dan kondisi yang terjadi pada saat itu.

Ungkapan ini mengingatka pada orang agar bertindak secara cermat dan bijaksana dalam menghadapi masalah dalam situasi dan kondisi apapun.

22) Paki ponggo sarinci to $\underline{b}$ e pingga

Maknanya membuang sesuatu yang tidak pasti demi mengejar yang besar (tapi belum pasti).

Ungkapan ini menggambarkan seseorang yang serakah atau boros. Dia berani melepaskan sesuatu yang sudah ada dan pasti di tangannya meski nilainya tidak 
besar demi mngejar yang lebih besar namun belum pasti.

Ungkapan ini biasa ditujukan pada orang yang sifatnya serakah, ia tidak bersukur dan todak puas dengan yang ada padanya.

23) Edera nggahi di lenga ponda ndai ma lengi

Maknanya jangan membicarakan kejelekan orang lain, kita sendiri mempunyaia kejelekan atau kekurangan.

Ungkapan ini berisi larangan agar jangan suka membicarakan kejelekan atau kekurangan orang lain, sementara kita sendiri punya kejelekan atau kekurangan.

Ponda biasa digunakan sebagai wadah untuk mengangkut atau menyimpan air. Ponda di sini diibaratkan sebagai pribadi yang mempunyai kekurangan dan keterbatasan.

24) Ndaina bou wira loja nahu waura wara di sabae

Maknanya kalau orang baru berencana kita harus sudah melakukannya

Ungkapan ini dikiaska pada orang yang baru saja merencanakan sesuatu sedangkan orang lain telah mengetahui maksud dan tujaun dari apa yang ia rencanakan. Ungkapan ini sering digunakan oleh para nelayan pada saat berlayar, seing para nelayan itu secara berkelompok. Di antara kelompok tersebut terdapa anak-anak dan orang tua selalu menegur anak-anak bila terlalu lambat mengembangkan layar, maka unghkpan tersebut yang selalu dikemukakan. Akhirnya ungkapan ini bukan sebagai contoh agar agar anak-anak agar cepat mengembangkan layar, melainkan juga suatu bagi siapa saja yang melakukan suatu pekerjaan jangan sampai lengah atau lambat.

Ungkapan ini mengingat bagi anak-anak maupun muda yang masih lambat dalam melakukan suatu pekerjaan.

25) Aina weli sahe ade diwu
Maknanya sebelum membeli barang harus melihat rupanya terlebih dahulu

Membeli kerbau dalam kubangan sulit kita mengetahui besar kecilnya, gemuk kurusnya kerbau yang hendak ditawar. Ungkapan ini mengisyaratkan bila membeli kerbau harus dalam kondisi yang bersih. Maka yang lebih luas dari itu adalah apabila berdagang atau membeli barang, kita memberikan mutu barangnya atau kondisinya baru ditawar (transaksi) sudah itu baru dibayar.

Ungkapan ini mengingatkan seorang yang mau berdagang agar membeli barang dagangan ahrus diteliti dahulu baru dibayar. Bila tidak demikian maka seorang akan mengalami kerugian. Akibatnya usaha yang akan dikembangkannya itu akan siasia saja.

\section{PENUTUP}

Berdasarkan hasil penelitian yang dilakukan oleh peneliti dapat disimpulkan bahwa makna dan penggunaan dari ungkapan tradisional yang terdapat pada masyarakat Bima berdasarkan data di atas yaitu; 1) menasehati, 2) memotifasi, 3) memberikan dukungan, 4) mengingatkan, 5) menyadarkan,dan 6) melengkapi, dan 7) menyemangati

\section{DAFTAR PUSTAKA}

Arifuddin, Nasaruddin, dkk. 1995. Nilai Pendidikan Dalam Cerita Rakyat Bima.

Departemen Pendidikan dan Kebudayaan: Mataram.

Baharuddin, D. Syahrial Isa, dkk. 1997. Iimbaga (Pribahasa) simahingun, Departemen Pendidikan dan Kebudayaan: Jakarta.

Danandjaja, James. 1984. Folklor Indonesia, PT. Grafiti Press: Jakarta. 
Djajasudarma, T. Fatimah, E. Kalsum, dkk. 1997. Nilai Budaya dalam Ungkapan Kebudayaan:Jakarta.

Hamidsyukrie, ZM, dkk. 1993. Inventarisasi dan Pengkajian Nilai-nilai Pancasila dalam Aforisme Bima, Departemen Pendidikan dan Kebudayaan: Mataram.

K., Ali M. 1996. Kamus Sejuta Ungkapan Peribahasa Indonesia, PT. Indah:Surabaya.

Keraf,Gorys. 2000. Diksi dan Gaya Bahasa, PT. Gramedia Pustaka Utama:Jakarta.

Mahsun. 1995. Dialektologi Diakronis sebuah Pengantar. FKIP. Gadjah Mada University Press: Yogyakarta.

Mansyur, Yusman, dkk. 1995. Ungkapan Tradisional Bima Kaitannya dengan Pendidikan Keluarga. Departemeii Pendidikan dan Kebudayaan: Mataram.

Mardalis.2003. Metode Penelitian suatu Pendekatan Proposal PT. Bumi Aksara:Jakarta. 